Article | Special Issue

\title{
The Peasant Movement and Great Refusal in the Philippines: Situating Critical Theory at the Margins
}

Jeffry V. Ocay

\begin{abstract}
This paper picks up on a dimension of Herbert Marcuse's model of critical theory that is greatly underdeveloped, and so much so that-particularly in the light of postcolonial theory-it is almost an embarrassment that what I refer to as "the margin," that is, a semicolonial periphery that is economically exploited, politically dominated and culturally hegemonized by imperialist powers, did not have a more important place in Marcuse's own work, and has not been far more the focus of Douglas Kellner and others who had fastened onto the Marxist Marcuse. In fact, Marcuse made only scattered statements about the nature of struggles in the society at the margins of the global system, and, when he did reference their plight and potential, he did not develop clearly how his theory could help in analyzing this context. This paper will look into the possibility of making Marcuse's notion of the Great Refusal relevant in the Philippines today, in an attempt to signal the possibility of redemptive alternatives to the struggle for emancipation. My main aim in this paper, therefore, is to show that the Filipino peasants in their plight, but also in their organization and indeed in their struggles, point to a way of life that escapes the apparently inescapable logic of technological domination. To that extent at least, they thus point to the possibilities of emancipation.
\end{abstract}

Keywords: Marcuse, peasant movement, Great Refusal, critical theory

\section{Introduction}

7 he Philippines, as we know, have been facing enormous social problems and forms of injustice, like abject poverty, massive unemployment, military oppression, extra-judicial killings, and all kinds of human rights violations. These problems have been compounded

(c) 2019 Jeffry V. Ocay

https://www.kritike.org/journal/special issue/ocay april2019.pdf

ISSN 1908-7330 


\section{SITUATING CRITICAL THEORY AT THE MARGINS}

and entrenched by the invasion of the country by capitalistic forces relayed and aided by local elites and local institutions. Hence, in a country "at the margins" like the Philippines, the domination that accompanies a capitalist order has actually been two-sided, by contrast with the domination Marcuse analyzed in his famous postwar writings: the modern, "technological" form of domination has indeed applied to the Filipino populations, leading to a form of "one-dimensionality" peculiar to Philippine society. But it has also been accompanied by more direct, brutal, primitive forms of oppression in the imposition of the foreign rule and its spirit onto the native population.

In the face of such enormous power of domination, combining the cultural, psychological and intellectual sophistication of "technological domination" with the naked brutality of so-called "primitive accumulation," what changes are there that a society like the Philippines could harbor anything like a sign or avenue towards the possibility of Marcuse's grand dream of a "Great Refusal"? In fact, I will try to show that it is the most oppressed of the oppressed that offers precisely a hope of this kind. However, contrary to Marcuse's contention that in late capitalist societies every form of opposition has been dissolved and has become part of the status quo, I will argue that the peasant movement in the Philippines provides substantive evidence to show that class antagonism and the consciousness of it are still a reality in the Philippines, and that Filipino critical consciousness, which climaxed in the 1896 Revolution, has survived and is on the rise again despite experiencing important setbacks during the Spanish, American, and Japanese period.

The fundamental question of this paper is how Marcuse's notion of the Great Refusal, which is understood both as a "rupture" with capitalist society and as a form of "critical thought" that can reject the prevailing repressive rationality, can be concretely articulated in the Philippines. I argue that the Great Refusal at the margins cannot depend on an established democracy, but must contend with political violence. I argue further that the New Left model advocated by Marcuse in the 1970s is however potentially viable because the cultural focus of the New Left-style politics confronts an alien hegemonic culture at the margins, rather than an autochthonous culture of capitalist consumption. In doing so, I will present a compelling case of Marcuse's notion of the Great Refusal based on my reinterpretation of Critical Theory in the neocolonial context.

\section{The Great Refusal in a Nutshell}

Let me begin with a brief presentation of Marcuse's notion of the Great Refusal before I fully articulate the specificity of this concept as it is

(c) 2019 Jeffry V. Ocay

https://www.kritike.org/journal/special issue/ocay april2019.pdf

ISSN 1908-7330

(c) $)$ BY-NC-ND 
applied in the Philippine context, especially the way in which it is embodied by the Filipino peasants.

Marcuse understands the Great Refusal as a kind of "negativity" both in thought and action, which enables the individuals to transform their present needs, sensibility, consciousness, values, and behaviour into a new radical sensibility, a sensibility that does not tolerate injustice and which resists and opposes all forms of control and domination. Douglas Kellner shows that for Marcuse, the Great Refusal is also a political refusal and revolt against the system of domination and oppression exacted by the capitalistic system. ${ }^{1}$ The Great Refusal for Marcuse is both individual and collective refusal, aimed at transforming the system of domination and oppression and the realization of a radical social change, the realization of a non-repressive, free, and happy society. It is collective inasmuch as it can only be realized if it takes the shape of a social movement. But it is also individual inasmuch as it requires the transformation of the individual's patterns of thought and of affectivity. In One-Dimensional Man, Marcuse maintains that it is only the Great Refusal that expresses a "truly revolutionary mode of opposition." 2

It is important to note that the Great Refusal is not simply an act of refusal for refusal's sake. As is clear, the Great Refusal is above all a struggle for and towards emancipation. It is a struggle towards the realization of a non-repressive society where people are freed from all forms of social control and domination.

It is important to note as well that the exact form of politics involved in Marcuse's notion of the Great Refusal is multi-dimensional. This can be observed in the switching of tone in Marcuse's works from One-Dimensional Man down to his last work, The Aesthetic Dimension. In One-Dimensional Man, "Repressive Tolerance," and An Essay on Liberation, Marcuse advocates confrontation politics, while in his Counterrevolution and Revolt, he advocates a United Front among the New Left. And, finally, in The Aesthetic Dimension, Marcuse emphasizes "art" as the ultimate form of the Great Refusal. While some scholars, like Douglas Kellner, argue that Marcuse's The Aesthetic Dimension abandons the idea of confrontation politics and a United Front, ${ }^{3} \mathrm{I}$ would argue the opposite. One might well see the shift from confrontation politics to aesthetics as called by a change in social conditions. The change of tactic, therefore, is not necessarily to be viewed as an abandonment of

${ }^{1}$ Douglas Kellner, Herbert Marcuse and the Crisis of Marxism (London and Berkley: MacMillan Press and University of California Press, 1984), 279. See also Jeffry Ocay, "Technology, Technological Domination, and the Great Refusal: Marcuse's Critique of the Advanced Industrial Society," Kritike: An Online Journal of Philosophy, 4:1 (June 2010), 54-78.

2 Herbert Marcuse, One-Dimensional Man: Studies in the Ideology of the Advanced Industrial Society (Boston, MA: Beacon Press, 1964), 255.

${ }^{3}$ See Kellner, Herbert Marcuse and the Crisis of Marxism, 291.

(c) 2019 Jeffry V. Ocay

https://www.kritike.org/journal/special issue/ocay april2019.pdf

ISSN 1908-7330

(cc) BY-NC-ND 


\section{SITUATING CRITICAL THEORY AT THE MARGINS}

previous strategies. It is basically a renewal of this tactic to suit the demand of the time.

The Great Refusal is thus a call for "social transformation" which is necessary in the sense that liberation requires a rupture in history and this rupture can only be performed through radical action. ${ }^{4}$ In some passages of "Repressive Tolerance," Marcuse fully endorses the possibility that this radical action will be violent. He writes:

If they [the oppressed and overpowered minorities] use violence, they do not start a new chain of violence but try to break an established one. Since they will be punished, they know the risk, and when they are willing to take it, no third person, and at least of all the educators and intellectuals, has the right to preach them abstention. ${ }^{5}$

Furthermore,

With all the qualification of the hypothesis based on an 'open' historical record, it seems that the violence emanating from the rebellion of the oppressed classes broke the historical continuum of injustice, cruelty, and silence for a brief moment, brief but explosive enough to achieve an increase in the scope of freedom and justice, and a better and more equitable distribution of misery and oppression in a new social system-in one word: progress in civilization. ${ }^{6}$

In these passages, historical violence at the hands of the oppressed is justified in terms of the Kantian paradigm to which the Marxist element of class struggle has been added. ${ }^{7}$

\footnotetext{
${ }^{4}$ Herbert Marcuse, An Essay on Liberation (Boston, MA: Beacon Press, 1969), 19. See also Jeffry Ocay, "Hegel Reframed: Marcuse on the Dialectic of Social Transformation," Philosophia: International Journal of Philosophy, 16:1 (January 2015), 102-109. See also Jeffry Ocay, "Heidegger, Hegel, Marx: Marcuse and the Theory of Historicity," Kritike: An Online Journal of Philosophy, 2:2 (December 2008), 46-64. For more discussion on Heidegger, see "Heidegger's Existential Philosophy," in Philo-notes (25 November 2017), <https://philonotes.com/index.php/ 2017/11/25/heidegger/>.

${ }^{5}$ Herbert Marcuse, "Repressive Tolerance," in Robert Paul Wolff, Barrington Moore, Jr., and Herbert Marcuse, A Critique of Pure Tolerance (Boston, MA: Beacon Press, 1965), 117.

${ }^{6}$ Ibid., 107.

7 Immanuel Kant, "Idea for a Universal History from a Cosmopolitan Point of View," in Political Writings, ed. by Hans Reiss, trans. by H.B. Nisbet (Cambridge: Cambridge University Press, 1970), 41-53.
}

(c) 2019 Jeffry V. Ocay

https://www.kritike.org/journal/special issue/ocay april2019.pdf

ISSN 1908-7330

(cc) BY-NC-ND 
The kind of revolution Marcuse envisions there is in fact different from what we have witnessed in history, for example, the French Revolution, the Bolshevik Revolution, and the Long March in China, because these violent upheavals were still premised on social conditions in which scarcity continued to prevail. They fought for essential rights and signalled the lack of fulfilment for the majority within the capitalist order, but they could not yet point to the full and proper transformation of the system. A more appropriate image of social transformation than the one to be gained from these previous struggles is the image of social transformation entailed in the concept of the "new sensibility." According to Marcuse, this new kind of revolution is

... driven by the vital need to be free from the administered comforts and the destructive productivity of the exploitative society, freed from smooth heteronomy, a revolution which, by virtue of this "biological" foundation, would have the chance of turning quantitative technical progress into qualitatively different ways of life-precisely because it would be a revolution occurring at a high level of material and intellectual development, one which would enable man to conquer scarcity and poverty. ${ }^{8}$

In Counterrevolution and Revolt, Marcuse argues that this revolution involves the "new sensibility," i.e., the transformation of the cultural and material basis of the society, the "needs and aspirations of the individuals," and their "consciousness and sensibility." 9 This "new sensibility" is revolutionary because it militates against technological domination. It militates against the numbing effect of the functional language of the consumerist society and at the same time shatters the kind of "false consciousness" that this language engenders.

With this novel form of revolution, the Marxist notion of "proletariat" as the sole agent of radical change has been significantly revised. Despite the fact that Marcuse saw that violence is sometimes ineluctable, he made it very clear that in a highly advanced society this tactic should not be employed. A struggle which attempts to seize power directly from the centers of political control, Marcuse says, should not be resorted to because in the advanced industrial society, the military and police power have been so

\footnotetext{
${ }^{8}$ Marcuse, An Essay on Liberation, 19. See also Jeffry Ocay, "The Freudian Marxist: Herbert Marcuse on the Psychology of Domination, Resistance, and Emancipation," Silliman Journal, 53:1 (January-June 2012), 156-179.

${ }^{9}$ Marcuse, Counterrevolution and Revolt (Boston, MA: Beacon Press, 1972), 16-17. 


\section{SITUATING CRITICAL THEORY AT THE MARGINS}

organized in the hands of an effectively functioning government. More importantly, such tactic surely would not draw support from the working class due primarily to the prevalence of reformist consciousness among them. ${ }^{10}$

Marcuse assumes he is talking about societies at the center of the system. But what about the societies "at the margins," like the Philippines? Here, his famous concept of "the New Left" and his notion of "radical sensibility" take on new meanings. As I will show later, at the margins, the system uses a combination of technological domination and direct violence. The imposition of an alien way of life made to suit colonial powers and direct imposition of unfair economic treaties and political and military agreements. In this case, the Great Refusal takes on different shape. First of all, the question of violence is different from what it is in countries at the center. In countries at the margins, there was the problem of armed power, of army and police, and transnational corporations. Thus, the struggle against colonialism at the margins was a violent struggle. Second, the model of "the New Left," an old model, now defunct in the West, also takes on different form at the margins. For Marcuse, the New Left is not a single organization with the same ethos as the Communist Party of the Philippines or the National Liberation Fronts in general. Rather, it refers to the different minority groups like the student's movement, women's movement, labor unions, peasant movement, and other politically inclined groups that struggle for liberation. For Marcuse, these forces are concrete expressions of the Great Refusal because they define the limits of the established societies and signal the impending rupture of history. ${ }^{11}$

The New Left, which for Marcuse is the only possible counterforce in the advanced industrial society, must "... assume the vast task of political education, dispelling the false and mutilated consciousness of the people so that they themselves experience their condition, and their ambitions, as vital needs and apprehend the ways and means of their liberation."12 Thus, as Marcuse argues, the revolution driven by the new sensibility must be brought

${ }^{10}$ Ibid., 43. Although Marcuse is convinced that the working class is no longer the sole agent of the revolution, he continues to believe that they remain the most decisive revolutionary force. The acquiescence or complicity of the working class to the system of control and domination does not mean complete dissolution of opposites in the advanced industrial society. This dissolution is only a momentary one. Marcuse continues to believe that the working class remains a revolutionary class. The power to subvert the oppressive society lies dormant in their very consciousness but so ripe for explosion once ignited. See also Ismael Magadan, Jr., "Democracy as Critique: Re-actualizing Jürgen Habermas' Theory of the Public Sphere," Social Ethics Society Journal of Applied Philosophy, 3:1 (October 2017), 15-32.

11 Marcuse, An Essay on Liberation, 6. See also Jeffry Ocay, "Eroticizing Marx, Revolutionizing Freud: Marcuse's Psychoanalytic Turn," Kritike: An Online Journal of Philosophy, 3:1 (June 2009), 10-23.

12 Marcuse, Counterrevolution and Revolt, 28.

(c) 2019 Jeffry V. Ocay

https://www.kritike.org/journal/special issue/ocay april2019.pdf

ISSN 1908-7330

(cc) BY-NC-ND 
to the political arena. This is now what Marcuse suggests in order to materialize emancipation: refuse, resist, and repel all forms of social control and domination. This programme will mean something different and perhaps easier to implement in countries "at the margins" because it is easier to reject alien way of life and return to original culture and question of language. A return to the indigenous mode of work, consumption habit, and distribution, which primarily hinges on the notion of "cooperation" exemplified by the baranganic system of the pre-Hispanic Philippine society, can also be viewed as the best alternative because it would mean a redirection of the capitalist mode of production towards the satisfaction of the senses and imagination of the individuals. According to Marcuse, this would weaken the Establishment and eventually leads to the demise of the capitalistic system. ${ }^{13}$

\section{The Peasant Movement and the Great Refusal in the Philippines}

But why the peasant movement despite the fact that there are a great number of active social and political movements in the Philippines today, such as the student movements, the women's movements, and the labor unions, that also struggled and continue to struggle against American-led capitalism? The privilege of any such movements located "at the margins" of the system, is that as soon as their particular struggle links the specific demands that they make and the specific forms of injustice that they denounce, to neocolonial policies and imperialist domination premised on a capitalistic logic, they immediately point to a possible "outside" of the system: first, they highlight "from the outside" the real violence and destructive potential of the system, a violence and destructive potential that has become invisible "at the canter"; and second, they also embody other ways of living and organizing society. But this view "from the outside" is precisely what Marcuse envisioned the Great Refusal should achieve, both in critical and pragmatic terms. "At the center," only Art for him was able to maintain this possibility. In countries at the margins like the Philippines by contrast, many radical movements embody this possibility much more explicitly and concretely. If we recall, an important implication of Marcuse's model was that "the truth and the freedom of 'negative thinking', of the Great Refusal, have their ground and reason" 14 in those movements that stay outside the established capitalist system. This means that exception from and resistance to capitalist domination comes from those who are not completely contained within the system per se yet receive the harshest exploitation.

${ }^{13}$ Ibid., 43.

${ }^{14}$ Marcuse, One-Dimensional Man, 222. Emphasis mine. 


\section{SITUATING CRITICAL THEORY AT THE MARGINS}

The student movements, for example, the National Union of Students in the Philippines, the Student Christian Movement of the Philippines, the League of Filipino Students, Kabataang Makabayan (Nationalist Youths), and ANAKBAYAN Philippines (Sons and Daughters of the People), have joined for a long time force in resisting the onslaught of imperialism against Philippine education. The women's movements like GABRIELA (General Assembly Binding Women for Reforms, Integrity, Equality, Leadership and Action), Kababaihan (Women), the historic MAKIBAKA (Makabayang Kilusan ng Bagong Kababaihan or Nationalist Movement of New Women), and many others, struggled not only against domestic violence and other forms of injustice committed against women, but also against capitalist exploitation in the country. Much as the labor unions, such as, the Kilusang Mayo Uno (May First Labor Movement), an umbrella organization of many progressive labor associations in the Philippines, fight for the rights of the workers such as better working conditions and just pay, it is also one of the staunchest critics of US imperialism. Indeed, as these movements clearly fight not only for the classical goal of justice and equality, but also for national liberation, there is no doubt that these movements are also expressions of what Marcuse calls the Great Refusal.

Amongst all the movements listed, however, one in particular appears to me to be the most eminent (if unlikely) embodiment of the Great Refusal, at least in its spirit: namely, the peasant movement. My emphasis on the peasant movement is founded first of all on the fact that they are probably the most brutalized of Filipino populations to have suffered from direct or indirect capitalist exploitation (whether imposed through the colonial powers or not). The full impacts of trade liberalization that started with the PayneAldrich Act in 1909 hit the peasants the deepest and marginalized them severely. For sure, although it is true that elements of the discourse and actions of the student movements, the women's movements, and the labor unions can be considered as expressions of the Great Refusal, in a country like the Philippines, it is in fact the peasant movement that embodies the most potent critique of and resistance to capitalist domination.

But that dimension is of course by far not sufficient to support my claim that the peasant organizations and struggles incarnate the basic principles of what is required that would lead to something like a "Great Refusal." The force of the peasant movement also lies in their numbers and, most importantly, in their alliance with peasant movements in other countries "at the margins." As Walden Bello argues, the international movement of small farmers and peasants has been one of the most dynamic sources of resistance against capitalistic domination in recent years. ${ }^{15}$ Against the false

${ }^{15}$ Walden Bello, The Food Wars (Manila: Advil, 2009), 148.

(c) 2019 Jeffry V. Ocay

https://www.kritike.org/journal/special issue/ocay april2019.pdf

ISSN 1908-7330

(cc) BY-NC-ND 
hope of neoliberal propaganda, if a country like the Philippines is to experience real emancipation, it will have to touch real masses in ways that are real for them. Rather than the false hopes attached to the inclusion into an industrial, consumer society, an alternative, that is, a more just and flourishing society, would have to be found in the very structures of peasant life. And thirdly, as a matter of fact, in the past history of the Philippines, it is the peasant masses that have been the most potent agents of resistance to domination. Here, the masses of peasant population become another argument: they represent a serious political force.

History shows that the Filipino peasants have always played a crucial role in the fight against colonialism. During the Spanish period, as we already know it, most, if not all, of the more than 200 revolts against the Spanish regime were waged by the peasants themselves. The one led by Diego Silang, and later by his wife Gabriela, is a classic example. Even the 1896 Revolution was primarily composed of peasants, despite the fact that it was founded by the proletarian Andres Bonifacio. During the American period still, the forces that struggled for national liberation were predominantly peasants. The Macario Sakay revolt, the last group to fight the Americans during the Filipino-American War, was very much dependent upon the peasantry. The Hukbo ng Bayan Laban sa Hapon (People's Army Against Japan), or simply the $H u k$, that valiantly fought the Japanese during the Second World War and then against the Americans during the postwar period were mostly peasants from central Luzon. And today, the New People's Army (NPA), the fiercest group that fights against imperialism, bureaucrat capitalism and feudalism is basically peasant by composition.

Although the peasant movement in the Philippines began as a struggle for just landlord-tenant relations, reasonable land rent, and land ownership, in the wake of capitalism vis-à-vis the establishment of the Communist Party of the Philippines, it has explicitly become an anti-capitalist movement. In the course of history, the Filipino peasants were able to relate the struggle against land to the struggle against colonialism, and now to the struggle against American-led capitalism. For example, today, issues of sovereignty, such as unjust trade relations and foreign military base agreements, have been articulated mostly by the peasants themselves or by movements that draw strength from the peasants.

To show how the peasants' struggle for land became an anti-capitalist movement as well as how the peasants were excluded in the capitalist system, thus excluding them from what Marcuse calls "one-dimensional society," I will discuss briefly the way in which American-led capitalism in the Philippines have impoverished the peasants and made them more and more landless, thereby causing the crystallization of the latter's resentment-to a point where they could begin to embody the principles of the Great Refusal. 


\section{SITUATING CRITICAL THEORY AT THE MARGINS}

It must be remembered that when the United States decided to annex the Philippines at the turn of the $20^{\text {th }}$ century, there was already a group of landed Filipino elites that dominated Philippine politics. These landed elites had already benefited from the export of agricultural products during the second half of the $19^{\text {th }}$ century. Because the Americans were fully aware that the Filipino revolutionaries, especially the peasants, continued to resist American colonial government, and because they knew that the peasants posed as a threat to the local elite, the Americans had to form an alliance with these local elite. To do this, the Americans continued the Spanish policy on the export of agricultural products, thus reinforcing the position of the landed elite. For the rest of the $20^{\text {th }}$ century, the strong alliance between the Americans and the Filipino landed elite, which later helped form what is now known as "patron-client" relationship, have left a deep imprint on the economic and political landscape of the Philippines. James Putzel, a renowned scholar on agrarian reform in the Philippines, writes: "The US built upon the economic and political legacy of Spanish rule, shaping both the economic and state structures that would characterize the Philippines for the rest of the $20^{\text {th }}$ century." 16

To reinforce their policy toward the Philippine economy, the American colonial government enacted the Philippine Organic Act in 1902, the Torrens Titling Systems also in 1902, and the Public Land Act in 1903. The Philippine Organic Act, which served as the constitution of the American colonial government until 1916, had "limited the size of public lands that could be acquired by individuals to 16 hectares (later amended to 100 hectares) and by foreign corporations to 1, 024 hectares." 17 The Torrens Titling System, on the other hand, beefed up the Philippine Organic Act by allowing foreign corporations to have absolute ownership over these lands. According to Putzel, the Torrens Titling System further deprived the peasants of their right to own the land they deserved because they were mostly ill-informed about the system, not to mention the fact that most of them did not have the necessary means to apply for land title. ${ }^{18}$ Nonetheless, the American colonial

${ }^{16}$ James Putzel, A Captive Land: The Politics of Agrarian Reform in the Philippines (Quezon City: Ateneo de Manila University Press, 1992), 51. Amado Guerrero also writes: "When the United Sates in its imperialist greed seized the Philippines for itself, it was very conscious of the necessity of retaining feudalism so as to provide itself continuously with such raw materials as sugar, hemp, coconut and other agricultural products." See Amado Guerrero, Philippine Society and Revolution (Oakland, California: International Association of Filipino Patriots, 1979), 93.

17 Putzel, Captive Land, 52. Emphasis added. See also Jeffry Ocay, "The History of Domination and Resistance in the Philippines: From the pre-Hispanic through the Spanish and American Period," Lumina: Interdisciplinary Research Journal of Holy Name University, 21:1 (March 2010), 35-61.

${ }^{18}$ Ibid., 53.

(c) 2019 Jeffry V. Ocay

https://www.kritike.org/journal/special issue/ocay april2019.pdf

ISSN 1908-7330

(c) BY-NC-ND 
government offered the Public Land Act in 1903 to enable the landless peasants to acquire their own lands. This law gave all Filipinos the right to acquire 16 hectares of public lands but with the condition that they establish homesteads and cultivate it for five consecutive years for a nominal fee. However, like the Philippine Organic Act and the Torrens Titling System, the Public Land Act was also unsuccessful in its attempt to solve the problem of landlessness in the Philippines because, as they "had no tradition of living on isolated farms, but rather live in barrios, or village neighborhoods," 19 the Filipino peasants were unresponsive to this Act. Consequently, many peasants became more and more landless while several big corporations, local and foreign, fared well under US rule, such as, the Tabacalera and Hacienda Luisita. The Tabacalera alone had acquired about 15, 452 hectares in Cagayan Valley by 1913.

The American colonial government later maneuvered the public land acquisition in order to expand US agribusiness and mining industries in the Philippines. Thus, by the 1920s, several big American corporations had penetrated the Philippine market. Notable among them was the Philippine Packing Corporations, (now named Del Monte Philippines), Dole, Stanfilco, Firestone Rubber, Benguet Consolidated, Lepanto, and Atlas Consolidated. Established by the American agribusiness giant, then known as the California Packing Company, Del Monte Philippines alone acquired vast tracts of lands in Bukidnon for pineapple plantations. The American colonial government then facilitated Del Monte's expansion by establishing an agricultural colony in Bukidnon. The 14, 000 hectares of agricultural land in Libona and Santa Fe which were converted into a US Naval base were leased to Del Monte and became Bukidnon Pineapple Reservation. Del Monte was also allowed to acquire an area within the agricultural colony and to finance homesteads that would raise pineapples.

As more and more Filipino peasants became dispossessed due to the establishment of these big plantations and mining industries, it seemed that the colonial government had never been sincere in introducing land reforms to the Filipino population. According to Amado Guerrero, these were sham land reforms because they only facilitated the acquisition of large public lands by US agricultural corporations, Filipino landlords and bureaucrats. ${ }^{20}$ As a direct response to these sham land reforms along with other land-related inequalities, agrarian unrest exploded in the 1940s and 1950s. The Huk rebellion in Central Luzon was the most notable among them. In response to this crisis, land reforms continued to be undertaken by the government during the postwar period, particularly from the Roxas administration down

\footnotetext{
${ }^{19}$ Ibid.

${ }^{20}$ Guerrero, Philippine Society and Revolution, 96.
} 


\section{SITUATING CRITICAL THEORY AT THE MARGINS}

to Quirino, Magsaysay, Garcia, and Macapagal. However, most Filipino scholars believe that just as the previous ones, these land reforms were highly ineffective, that they remained under the influence of the American capitalists and their allies, the local elites. During the Ramon Magsaysay administration, for example, land reform was done in the form of resettlement ${ }^{21}$ wherein peasants were forced to move to the uninhabited hilly and mountainous regions of the country with less, if not without, financial support from the government.

In 1972, shortly after he assumed absolute power by declaring martial law, Ferdinand Marcos issued Presidential Decree No. 2, declaring the whole country as a land reform area "in order to accelerate the implementation of reform both to stimulate agricultural development and to remove the source of rural unrest." 22 In particular, Marcos's land reform program aimed to abolish sharecropping, transform tenants to owner-cultivators, and create a market for industry. ${ }^{23}$ Yet, the decree proved once again to be highly ineffective despite its commendable intents. Throughout his 21-year long rule which ended in 1986, Marcos had redistributed very little land to the peasants while huge amount of lands was still concentrated in the hands of the landed elite and foreign agribusiness corporations. Moreover, surveys taken during the 1970s and early 1980s showed that sharecropping was still extensive. For example, a 1978 study showed that 44 per cent of rice and corn farmers were share tenants and that it was the dominant form of tenancy in 7 out of 11 regions surveyed. ${ }^{24}$

When Marcos was unseated in 1986, his successor, Cory Aquino, introduced the Comprehensive Agrarian Reform Program (CARP) in an attempt to implement a genuine and comprehensive land reform program that would redress the decades-long grievances of the peasants. But like the rest of the previous land reform programs, Aquino's CARP was far from being successful. "Having passed the burden of defining the program to Congress, the landlord-dominated legislature produced a law that reflected the interests of the propertied rather than the program's intended beneficiaries." 25 In addition, Aquino seemed to have been inconsistent with her promise of genuine and comprehensive land reform as outlined in the platform during her bid for the presidency. It became evident in her address to the press in June 1986 regarding her first 100 days in office. Aquino stated

\footnotetext{
${ }^{21}$ Resettlement, however, started with the Quezon administration and was organized under the National Land Resettlement Administration in 1939. See Guerrero, Philippine Society and Revolution, 96.

${ }^{22}$ Putzel, Captive Land, 124.

${ }^{23}$ Ibid.

24 Ibid., 138

${ }^{25}$ Cecilia S. Ochoa, Siglo-Saka: A Century of Peasant Struggle and Contributions to Philippine Nationhood (Quezon City: Philippine Peasant Institute, 1998), 23.

(c) 2019 Jeffry V. Ocay

https://www.kritike.org/journal/special issue/ocay april2019.pdf

ISSN 1908-7330
}

(c) BY-NC-ND 
that only idle public lands would be covered by CARP. ${ }^{26}$ Surprisingly, what Aquino's "genuine and comprehensive land reform" program aimed at was not to redistribute large agricultural lands but to provide services to small farmers in the form of credit, marketing, and technological support. As one could see, this obviously safeguarded the interests of the big agribusiness corporations and the landed elite, including her family which owned the Hacienda Luisita. Thus, time and again, the peasants were deprived of their right to own the land they tilled while the landed elites who dominated Philippine politics and backed up by the United States continued to own huge tracts of agricultural lands and control agribusiness in the country.

The Ramos administration witnessed the continued implementation of CARP, yet no new genuine approach was introduced to correct its loopholes. Although it is reported that more lands were redistributed during the Ramos administration than Marcos's and Aquino's combined, this did not change the fact that the large private haciendas which are the root cause of inequality and injustice in the countryside remained in the hands of the landed elite while a majority of the peasants remained landless. ${ }^{27}$

Now, as we can see, the introduction of American-oriented capitalism in the Philippines contributed not only to the deepening of land problems and the increasing number of tenants, but also to the consolidation of landlord political and economic power. Up until now, the Philippine political landscape is dominated by the Filipino landed elites or by politicians who have benefited from agriculture-related industry. As a result, and as Cecilia Ochoa observes, the government has done little to address the century-old problem of landlessness in the Philippines. ${ }^{28}$ On the contrary, what we witness today is the intensification of capitalist domination in the form of land grabbing, manipulation of agribusiness, militarization, and political killings, targeting especially the leaders of peasant organizations.

The displacement and dispossession of the peasants, that is, their exclusion from the affairs of the State did not ensue solely from the series of land acts instituted by the American colonial government during the first half of the $20^{\text {th }}$ century and by the local political leaders after independence. The establishment of unequal trade agreements between the United States and the Philippines as well as the intrusion of transnational corporations into the Philippine market also played a big part. As is well known, the establishment of free trade in the Philippines via the Payne-Aldrich Act in 1909 and the Bell Trade Act in 1945 further impoverished the great majority of the population. And because no less than 75 per cent of the Filipino masses are peasants, there is no doubt that it is the peasants themselves who suffered directly from the

\footnotetext{
${ }^{26}$ Putzel, Captive Land, 199

${ }^{27}$ Ochoa, Siglo-Saka, 24.

${ }^{28}$ Ibid.
}

(c) 2019 Jeffry V. Ocay

https://www.kritike.org/journal/special issue/ocay april2019.pdf

ISSN 1908-7330 


\section{SITUATING CRITICAL THEORY AT THE MARGINS}

brunt of neoliberal policies. Let us take the issue on rice production, for example, in order to show how the peasants and majority of toiling Filipino masses were victimized by such neoliberal policies. ${ }^{29}$

Much as rice has been a staple food for the Filipinos for many yearsit has become, in fact, an integral part of their culture over the years-the majority of the Filipino peasants have been dependent upon rice production for survival. Due in part to the backwardness in technology and the chronic problem of landlessness that has characterized the agricultural economy of the Philippines for many years, most peasants produce rice only enough for their family's subsistence. For sure, long before neoliberal policies were introduced in the Philippines, there was already rice shortage in the country. The introduction of neoliberal policies in the country has, to some extent, contributed to the development of rice production technology as key rice research institutes, such as, the International Rice Research Institute (IRRI) have been established in the country in the wake of neoliberalism. With this innovative technique in rice production, of course, along with much-needed government's financial support to rice farmers, it would seem that the chronic food crisis in the country should have been well addressed, thereby contributing, however little, to the amelioration of the plight of the peasants in the countryside. Yet, as it turned out, the peasants have remained hardpressed and far from reaping the benefits of such breakthroughs in rice production because, in addition to the lack of government financial support for the peasants and chronic landlessness, the powerful landed elites have cornered the profitable rice business. Most of the huge tracts of rice farms in the Philippines today are owned by the corporate agribusiness, if not by the rural elites. Even if some peasants own small parcels of lands, they could not fully take advantage of the advancement in rice production technology due to lack of capital. The government has failed to provide the peasants, especially the rice farmers, with the financial support necessary to attain maximum production output. Consequently, the peasants have been forced to take on loans from banks and, frequently, from usurious lending institutions which have mushroomed not only in the highly urbanized areas but also in the remote rural localities in recent years. Needless to say, this has further impoverished the peasants because a big portion of their profit goes to the interest of their loans. Moreover, because these loans usually require land title as collateral, many peasants have lost their lands after they became unable to pay.

${ }^{29}$ For a powerful indictment of the neoliberal economic policies pursued in the Philippines since the overthrow of the late dictator Ferdinand Marcos, see Walden Bello, Marissa de Guzman, Mary Lou Malig, and Herbert Docena, The Anti-Development State: The Political Economy of Permanent Crisis in the Philippines (London and New York: Palgrave, 2005).

(c) 2019 Jeffry V. Ocay

https://www.kritike.org/journal/special issue/ocay april2019.pdf

ISSN 1908-7330

$(\mathrm{Cc}) \overline{\mathrm{BY}-\mathrm{NC}-\mathrm{ND}}$ 
In addition, the problem of rice shortage in the Philippines has a lot to do with the capitalist-oriented export/import policy introduced by the United States at the turn of the $20^{\text {th }}$ century. Again, when the Payne-Aldrich Act was introduced in 1909, which made "free trade" a national economic policy, the Philippines began to export raw materials, such as, copra, sugar, tobacco, and other agricultural products mainly to the United States. Because the production of these so-called cash crops offered better returns than rice, more and more rice planters turned to the production of these cash crops. As a result, huge tracts of agricultural lands were converted into sugar plantations, such as the ones in Negros Occidental, dubbed the sugar capital of the Philippines; hundreds of thousands of agricultural lands in Central Luzon and Mindanao were also converted into coconut plantations; and, huge tracts of lands were also cultivated for tobacco production in Northern Luzon, most notably the Ilocos region. Since then and throughout the $20^{\text {th }}$ century, the production of export crops has been further encouraged, and, in the event of rice shortage, the government had to import rice from neighboring rice-producing countries like Vietnam, Thailand, Indonesia, and China. Until today, despite the fact that the Philippines is primarily a riceproducing country, it continues to import rice to feed its growing population. As a matter of fact, in The Food Wars, Walden Bello, reminds us that the Philippines is now the world's biggest importer of rice. ${ }^{30} \mathrm{It}$ is reported that the Philippines imported 900, 000 metric tons of rice in 2004 and 1.827 million metric tons in 2007.31

What this discussion shows is that the peasant populations have been the direct victims of capitalist domination as it has developed in the Philippines. They are the largest and most exploited of all social classes in their country. And to begin with, it is precisely in that respect that they can represent a force that corresponds to Marcuse's vision of a "Great Refusal." As the direct victims of the neocolonial exploitation that accompanies realexisting capitalism "at the margins," they are in no way included in the logic of the system as other populations are. But the great force of the peasant movement is also its sheer number and indeed, as I will try to show, the alternative, non-consumerist ways of life it can propose. ${ }^{32}$

\footnotetext{
${ }^{30}$ Bello, Food Wars, 54-67.

${ }^{31}$ See "NFA urged to sue Arroyo, Yap over rice imports," in ABS-CBN News (30 July 2010), <https://news.abs-cbn.com/nation/07/30/10/nfa-urged-sue-arroyo-yap-over-rice-imports $>$.

${ }^{32}$ It is worth noting that when Marx was forced to move to London in 1849 after experiencing the defeat of the European Revolutions of 1848, he began to write on societies that were peripheral to the capitalist system and examined their prospects for revolution and as sites for resistance to capital. Here, Marx showed how a revolution could be successful if the peasant movement could be linked up with the working-class movements. This shows that Marx saw the peasant movement as a potential source of hope for social transformation. See Kevin B. Andersen, Marx at the Margins: On Nationalism, Ethnicity, and Non-Western Societies (Chicago: The
} 


\section{SITUATING CRITICAL THEORY AT THE MARGINS}

To recall, Marcuse's concept of the Great Refusal puts great emphasis on those groups or forces, such as, "the outcasts and outsiders, the exploited and persecuted of other races and other colors, the unemployed and the unemployable," 33 that are located outside the prevailing system. Although he never completely jettisoned Marx's "proletariat" as a revolutionary force, Marcuse believes that in a highly technological society, a rupture in history or simply any serious form of "liberation," which the Great Refusal aims to achieve, can no longer be carried out by the proletarians themselves or by armed men but by such groups and forces that are not completely contained within the capitalist system. They are, for Marcuse, the only possible agents of social transformation because all other groups have somehow been included in the mechanisms that allow the system to perpetuate itself, notably by making them accept a language and a way of feeling and looking at social life that serve the system's self-reproduction. In the Philippines, the peasant movement and other marginalized groups best exemplify the qualities of such agents of social transformation.

It is important to note at this point that when I speak of the peasants as pointing to the most serious possibilities of social transformation in the Philippines, I am not referring to the entirety of the Filipino peasants. Not all peasants in the Philippines today are in the position to embody resistance to capitalist domination because many of them are thoroughly subjected to state capitalism and militarization, especially those who are located in the lowland regions. The peasants in these regions have already been included into the national and international markets and are under direct government control so that the idea of resistance to domination makes little sense for them. According to Gary Hawes, the massive intrusion of state capitalism and a growing militarization (against which the peasant cannot resist), coupled with better transportation and communication in the lowland regions of the Philippines has made resistance less likely. ${ }^{34}$ It is therefore not surprising that it was in these regions in which the Communist Party of the Philippines found it difficult to establish a mass base, ${ }^{35}$ that the Huk rebellion failed in the 1940s and 1950s, that the green revolution strategy of the late dictator

University of Chicago Press, 2010), 2-3. For related study on the struggle of the indigenous peoples, see Jeffry Ocay, "Ethics of Refusal: Globalization and the Penan People's Struggle for Recognition," Budhi: A Journal of Ideas and Culture, 19:2-3 (2015), 169-195.

${ }^{33}$ Marcuse, One-Dimensional Man, 256.

${ }^{34}$ Gary Hawes, "Theories of Peasant Revolution: A Critique and Contribution from the Philippines," World Politics, 2:2 (January 1990), 269.

${ }^{35}$ However, recent history shows that the Communist Party of the Philippines (CPP) and its armed wing the New People's Army (NPA) have gained considerable support from the peasants of these regions. Take for example the case of the Negros and Bohol. Many red fighters have already penetrated the lowland areas of these provinces.

(c) 2019 Jeffry V. Ocay

https://www.kritike.org/journal/special issue/ocay april2019.pdf

ISSN 1908-7330

(cc) BY-NC-ND 
Ferdinand Marcos which aimed to quell agrarian revolts gained considerable acceptance, and that major US and Philippine military bases are located. If we relate this to Marcuse, the philosopher would have argued that these peasants, because they are incorporated into the larger national and international markets, are already contained within the confines of the capitalist system, that technological rationality has already invaded their consciousness; thus, resistance cannot be expected from them. However, this does not discount the fact that a greater portion of the peasant population continues to practice values that are antithetical to capitalism, values in particular that continue to be informed by the basic features of the precolonial and pre-capitalist baranganic society. Thus, the best agents of social transformation that I am referring to in this paper are the peasants who are located in the periphery, in the more marginal, upland agricultural areas where they produce agricultural products for the local economy and for family consumption.

Thus, the peasants that I am referring to in this paper as the best agents of social transformation are those who are located in the periphery, in the more marginal, upland agricultural areas where they produce agricultural products for the local economy and for family consumption.

I want to add that this paper does not intend to undermine the more radical peasants, such as, the members of the Communist Party of the Philippines and its revolutionary wing, the New People's Army, and the Kilusang Magbubukid ng Pilipinas (Peasant Movement of the Philippines), who resorted to militant struggle against land grabbing, militarization, and other forms of injustice brought about by capitalism. In fact, Marcuse believed that this kind of struggle is inevitable given the circumstances, that if the most oppressed of all the social classes decide to march for freedom in a violent manner, no one has the right to teach them abstention. ${ }^{36}$ What this paper wants to do instead is look for alternative ways of resisting capitalist domination that are peculiar to the Filipino peasants, ways that are both in line with the Marcusean notion of "resistance from the outside" and different from the orthodox mode of resistance where seizure of power at the "center" is aimed at. Thus, the peasant opposition that I want to study here has nothing to do with the classical revolutionary forces that dominate in history. It is this point that I now want to develop briefly.

36 Yet, in a society where the police and the military have been so well organized to defend the status quo, Marcuse also agrees that a kind of struggle that attempts to seize power from the "center" should be avoided. For Marcuse, this is not only an ideologically misguided struggle but political suicide. See Herbert Marcuse, "On The New Left," in The New Left and the 1960s: Collected Papers of Herbert Marcuse, Vol. 3, ed. by Douglas Kellner (London and New York: Routledge, Taylor and Francis Group, 2005), 124. 


\section{SITUATING CRITICAL THEORY AT THE MARGINS}

I believe that the peasant movement in the Philippines is potentially a good expression of the Great Refusal as it situates itself explicitly and substantially outside the main ideological discourses of the day, between neoliberal justifications and the classical Marxist-Leninist-Maoist discourse that continues to prevail in the Philippines today, and because it challenges inequalities in terms that are different from the main ideological game. This uniquely Marcusean way of resisting capitalist domination takes many forms. I will only concentrate on the most salient points.

First, the Filipino peasants I am referring to oppose the current capitalistic logic and its forms of domination by reference to an alternative tradition of working, using, and sharing the land collectively and cooperatively. In many parts of the Philippine archipelago, there exists a strong indigenous practice of collective work which is called suyuan in Mindoro, jungos in Bohol, and junlos in many parts of Mindanao. This is a local practice by which the peasants pool their labor together in order to get the job done efficiently without the use of money, that is, without paying the labor each member of the suyuan or jungos or junlos expends. Ligaya LindioMcGovern explains this type of collective work in the following manner:

Peasants who have lands to till, usually as tenants, work together on one plot, which is under the care of one member of suyuan. Since many do the work, they finish whatever they need to do in a shorter time. Then they work on the plot of another member in the suyuan. They follow this pattern until every member has her or his work finished. ${ }^{37}$

This cooperative form of work is an effective alternative to a capitalistoriented type of work because it unties the peasants from surplus repression demanded of them by the capitalist society and frees them from the obligation of maximum individual performance. More importantly, such cooperative form of work enables the Filipino peasants to come up with a viable economic organization that allows them to control the marketing of their produce. They do this by establishing consumer and credit cooperatives at the village and

37 Ligaya Lindio-McGovern, Filipino Peasant Women: Exploitation and Resistance (Philadelphia, PA: University of Pennsylvania Press, 1997), 95. See also Jeffry Ocay, "Shifting Pattern and Sophistication of the American Colonial Domination in the Philippines: From Colonialism to Technological Domination," Silliman Journal, 55:1 (January-June 2014), 117-152. For a relevant discussion on marginalization in relation to race and immigration, see Andres Salvador, "Racism and Immigration: Is it racist to limit immigration?" in Philo-notes (27 November 2017), <https://philonotes.com/index.php/2017/11/27/racism-and-immigration/>.

(c) 2019 Jeffry V. Ocay

https://www.kritike.org/journal/special issue/ocay april2019.pdf

ISSN 1908-7330

(c) $)$ BY-NC-ND 
community levels. ${ }^{38}$ In principle, an alternative strategy of producing and consuming basic commodities that is both antithetical to a capitalist-oriented type of production process and yet ensures satisfaction of their vital needs, should spare the peasants from being crushed by imported products, such as imported rice, and from being swallowed by large-scale agribusiness as happened elsewhere in the country. In other words, this indigenous alternative of producing and consuming protects these Filipino peasants from the aggressive and destructive tendencies of technological development, which, according to Marcuse, perpetuates servitude amidst growing possibilities of freedom and which deepens poverty amidst abundance. Furthermore, their distance from the city centers combines with their social organization, itself revolving around an alternative, cooperative model of work, keeps them from being transformed into insatiable consumers whose consciousness is reduced into mere biological impulses that merely adjust to the technical processes of production. Following Marcuse, I would claim that this attitude to work, which is antithetical to the capitalist work ethic, and the consumption habits that go with it, constitutes a sphere that is not completely integrated into the capitalist system. As a result, through its sheer existence and its relative success it demonstrates the possibility of escaping a repressive society that develops only on the condition of accelerating waste, planned obsolescence, destruction, and exploitation of large populations. ${ }^{39}$

In the face of the tremendous power of modern industry, science and financial techniques, the appeal to indigenous modes of social organization and cooperative work might appear incredibly naïve. But this is only if one forgets the immensely destructive nature of contemporary technological rationality, a potential for destruction which drove Marcuse to seek for the possibilities for alternatives. To speak very simply, and if one lets oneself be guided by Marcuse's analysis: if the logic at work "at the center," which has been imported to the new emerging powers, and which has subjugated countries "at the margins" like the Philippines, is left to rule unchecked, only a catastrophe can emerge from it, either social (new wars) or environmental (climate change), or a combination of the two. Against this catastrophic

\footnotetext{
${ }^{38}$ The establishment of cooperatives as a way of countervailing capitalist domination, however, is not a monopoly of the Filipino peasants. Obviously, cooperatives are also present in other countries. What is unique to cooperatives established by the Filipino peasants is that it has retained the basic economic features of the pre-colonial and pre-capitalist baranganic society, that is, the peasants depend on each other for survival (cooperative labor) and exercise control over the means of production. For a recent study on the philosophy of work of the Filipinos in the periphery, see Jeffry Ocay, "Philosophy at the Margins: Exploring the Philosophy of Work of the Elderly People in some Remote Areas of Negros Oriental," Social Ethics Society Journal of Applied Philosophy, 1:1 (October 2015), 1-22.

${ }^{39}$ Herbert Marcuse, "Liberation from the Affluent Society," in The New Left and the 1960s: Collected Papers of Herbert Marcuse, 77.
} 


\section{SITUATING CRITICAL THEORY AT THE MARGINS}

background, the alternative model of social life presented by the barangay system, and indeed the historical struggles that were waged in its name, suddenly appear anything but sentimental.

However, it is very important to say that this emphasis on a traditional Filipino way of living and working together does not amount to a form of regression, that is to say, a return to a traditional form of production process where labor was still considered long and hard due to the absence of a more sophisticated technology. As a matter of fact, Marcuse was not opposed to all forms of technology when he denounced technological domination. The point to make is that the development of technology should be guided by the traditional attitude of the peasants toward work and consumption so that it would serve to disburden their toil and satisfy their vital needs. In this new type of production relations where technology takes central role, the people produce enough for the local economy and the family. There might be surplus but only in the sense of excess goods normally used for consumption, one that is not solely intended for circulation as "exchange value," or surplus intended for profit. ${ }^{40}$ As Kathy Nadeau also argues, this new economic set up, which reflects the economic set up of the pre-colonial and pre-capitalist Philippine society, is a direct negation of capitalism.

The type of society that emerges from this kind of socio-economic relations shows the bases of what Marcuse envisions as the good society. For Marcuse, according to Peter Lind, the good society is a social order which is primarily based on a cooperative form of labor necessary for the realization of freedom. ${ }^{41}$ Lind notes that this society allows a new homo faber (or the new individual with the new sensibility according to Marcuse) "to devote himself fully to his share of the collective social labor, to take a full part in decisions to produce this or that object and participate on an equal basis in the allocation of communal task." ${ }^{42}$ The peasant way of life provides a concrete example of such a communal form of social life, organized around cooperative work.

These Filipino peasants also point to the signs of a Great Refusal in the way in which they approach land distribution. As I showed above, the Philippine government failed to implement true and effective land reform. This prompted the Filipino peasants to promote a radical and indigenous alternative of implementing land distribution that goes beyond the confines of modern law. They do this in the form of "land occupation," a process of collectively occupying idle lands and making them productive. According to

\footnotetext{
${ }^{40}$ See Kathy Nadeau, "Peasant Resistance and Religious Protests in Early Philippine Society: Turning Friars against the Grain," Journal for the Scientific Study of Religion, Vol. 41 No. 1 (March 2002), 80.

${ }^{41}$ Lind, Marcuse and Freedom, 127.

${ }^{42}$ Ibid., 123.

(c) 2019 Jeffry V. Ocay

https://www.kritike.org/journal/special issue/ocay april2019.pdf

ISSN 1908-7330
}

(c) BY-NC-ND 
Lindio-McGovern, these idle lands are usually owned by absentee landlords and corporations. ${ }^{43}$ In Mindoro, for example, the first land occupation took place in Sablyan in 1984. Here, the peasants occupied huge tracts of idle lands, about 150 hectares, which were owned by Philippine Long Distance Telephone Company (PLDT). Lindio-McGovern notes that the peasants occupied the land collectively and simultaneously and began to make these idle lands productive. ${ }^{44}$ After the first harvest, however, the peasants were forcibly dispersed.

Although the Filipino peasants were eventually unsuccessful in their struggle for land ownership by way of land occupation, what is important is that their actions break with the familiar, with the routine ways of seeing and understanding reality. Theirs is a kind of struggle that differs from the traditional political opposition borrowed from the West. These efforts have allowed the peasants to challenge the state and the local capitalists in a unique sense which in fact corresponds to the kind of politics Marcuse envisioned, as politics that would step outside the mechanisms of reproduction of the system. For Marcuse, it is only through a methodical disengagement from and refusal of the established order, through an opposition from the outside, that a rupture with history can be signaled. ${ }^{45}$

Again, the appeal to this kind of social movement appears naïve only from a perspective that assumes that the standards of rationality are the ones implicit in the existing system. But if, following Marcuse, and indeed as concrete facts and history demonstrate, one doubts the actual "rationality" of that system, in terms of the real justice and real human flourishing, it systematically fails to deliver, then again the reference to the forms of struggle engaged in by the peasants becomes far from naïve. Indeed, it is worth noting that the reference to struggles by the poorest of the poorest, namely the native peasants, around the question of land distribution, has been tantamount in many other countries "at the margins," notably in South America, in Bolivia (Movement for Socialism of President Morales) and Mexico (and the Zapatista movement).

One specific example is particularly telling, in my mind, to highlight the novelty and effectiveness of farmers' struggle in resisting the established society and its concomitant system of domination. This is the example of the framers of the Higaonon from Sumilao, Bukidnon, and how they fought for land rights recognition. Their land of about 355.824 acres was grabbed by converting it into a hog farm by the San Miguel Foods Inc. The Higaonon tribe farmers petitioned the Department of Agrarian Reform (DAR) to issue a cease-and-desist order (CDO), but the Supreme Court of the Philippines

${ }^{43}$ Lindio-McGovern, Filipino Peasant Women, 86.

${ }^{44}$ Ibid., 87-95.

${ }^{45}$ See Marcuse, An Essay on Liberation, 6. 


\section{SITUATING CRITICAL THEORY AT THE MARGINS}

dismissed their case because they lacked legal standing. Yet the Higaonon tribe farmers decided to continue fighting for their ancestral land through extralegal means. Thus, on 10 October 2007, the 55 Higaonon tribe farmers started to march the 1, 055.7 miles long Sumilao, Bukidnon-Manila highway for 2 months, arriving in Manila on 03 December 2007. When they reached Manila, they staged a hunger strike for several days in front of Malacañang. On 17 December 2007, President Gloria Arroyo revoked the conversion order on the disputed 355.824 acres land in Sumilao, Bukidnon, resulting in the return of the land to the 55 members of the Higaonon tribe farmers. ${ }^{46}$

The success of the Higaonon tribe farmers is indeed an exceptional case in the history of the struggle for land rights recognition in less developed countries, and, perhaps, in the First World countries. It is because this struggle defies the reign of law yet receives due recognition by the law itself. This is what Marcuse would want to see in those subjects who struggle for radical social change.

\section{Concluding Remarks}

The foregoing is not certainly a full explication of the ways in which the Filipino peasants express the Great Refusal. Yet, the illustrations above, albeit brief, suggest that despite the overwhelming force of technological domination and other forms of social control, there remain in Philippine society forces that carry the hope of emancipation: the peasants themselves. Their attitude toward work and their consumption habit which continue to be informed by the cooperative values of the pre-colonial and pre-capitalist society, show that they are capable of demonstrating liberating tendencies within the established technological society. That is to say, if they were given the chance to own the land they till, to control the means of production, and to determine their own needs within the existing conditions of unbridled technological advancement, these people would be able to propound a valid alternative model of development opposed to what Marcuse calls repressive technological society. Of course, as Marcuse gestured toward the end of his seminal work One-Dimensional Man, the chance of this alternative is almost bereft of hope. The road to liberation, if it is attainable at all, is surely an arduous one. What this implies for the Filipino peasants is that no matter how hard they struggled for land rights recognition or for reasonable land rent or for liberation in general, success is far from guaranteed. Yet, they have to continue this struggle which appears to be the last remaining one in a society that becomes more and more one-dimensional. In the end, the Filipino

${ }^{46}$ Fundador S. Binahon, Jr., "The Higaonon," in National Commission for Culture and the Arts (30 April 2015), <https://ncca.gov.ph/about-ncca-3/subcommissions/subcommission-oncultural-communities-and-traditional-arts-sccta/central-cultural-communities/the-higaonon/>.

(c) 2019 Jeffry V. Ocay

https://www.kritike.org/journal/special issue/ocay april2019.pdf

ISSN 1908-7330

(c) $)$ BY-NC-ND 
peasants are burdened with the task of waging a perpetual opposition to the repressive technological society. As Marcuse writes, "We must always resist if we still want to live as human beings, to work and be happy." 47

The Graduate School, Eastern Visayas State University, Philippines

\section{References}

Andersen, Kevin B., Marx at the Margins: On Nationalism, Ethnicity, and NonWestern Societies (Chicago: The University of Chicago Press, 2010).

Bello, Walden, The Food Wars (Manila: Advil, 2009).

Bello, Walden, Marissa de Guzman, Mary Lou Malig, and Herbert Docena, The Anti-Development State: The Political Economy of Permanent Crisis in the Philippines (London and New York: Palgrave, 2005).

Binahon, Fundador, Jr. S., "The Higaonon," in National Commission for Culture and the Arts (30 April 2015), <https://ncca.gov.ph/about-ncca3/subcommissions/subcommission-on-cultural-communities-andtraditional-arts-sccta/central-cultural-communities/the-higaonon/>.

Guerrero, Amado, Philippine Society and Revolution (Oakland, California: International Association of Filipino Patriots, 1979).

Hawes, Gary, "Theories of Peasant Revolution: A Critique and Contribution from the Philippines," World Politics, 2:2 (January 1990).

"Heidegger's Existential Philosophy," in Philo-notes (25 November 2017), $<$ https://philonotes.com/index.php/2017/11/25/heidegger/>.

Kant, Immanuel, "Idea for a Universal History from a Cosmopolitan Point of View," in Political Writings, ed. by Hans Reiss, trans. by H.B. Nisbet (Cambridge: Cambridge University Press, 1970).

Kellner, Douglas, Herbert Marcuse and the Crisis of Marxism (London and Berkley: MacMillan Press and University of California Press, 1984).

Lindio-McGovern, Ligaya, Filipino Peasant Women: Exploitation and Resistance (Philadelphia, PA: University of Pennsylvania Press, 1997).

Magadan, Ismael Jr., “Democracy as Critique: Re-actualizing Jürgen Habermas' Theory of the Public Sphere," Social Ethics Society Journal of Applied Philosophy, 3:1 (October 2017).

Marcuse, Herbert, An Essay on Liberation (Boston, MA: Beacon Press, 1969). Five Lectures: Psychoanalysis, Politics, and Utopia, trans. by Jeremy

Shapiro and Shierry M. Weber (Boston: Beacon Press, 1970). Counterrevolution and Revolt (Boston, MA: Beacon Press, 1972).

\footnotetext{
${ }^{47}$ Herbert Marcuse, Five Lectures: Psychoanalysis, Politics, and Utopia, trans. by Jeremy Shapiro and Shierry M. Weber (Boston, MA: Beacon Press, 1970), 94. Italics added. 


\section{SITUATING CRITICAL THEORY AT THE MARGINS}

One-Dimensional Man: Studies in the Ideology of the Advanced Industrial Society (Boston: Beacon Press, 1964).

"Repressive Tolerance," in Robert Paul Wolff, Barrington Moore, Jr., and Herbert Marcuse, A Critique of Pure Tolerance (Boston, MA: Beacon Press, 1965).

"NFA urged to sue Arroyo, Yap over rice imports," in ABS-CBN News (30 July 2010), <https://news.abs-cbn.com/nation/07/30/10/nfa-urged-suearroyo-yap-over-rice-imports $>$.

Ocay, Jeffry, "Ethics of Refusal: Globalization and the Penan People's Struggle for Recognition," Budhi: A Journal of Ideas and Culture, 19:2-3 (2015).

"Eroticizing Marx, Revolutionizing Freud: Marcuse's Psychoanalytic Turn," Kritike: An Online Journal of Philosophy, 3:1 (June 2009).

"Hegel Reframed: Marcuse on the Dialectic of Social Transformation," Philosophia: International Journal of Philosophy, 16:1 (January 2015).

"Heidegger, Hegel, Marx: Marcuse and the Theory of Historicity," Kritike: An Online Journal of Philosophy, 2:2 (December 2008).

"Liberation from the Affluent Society," in The New Left and the 1960s: Collected Papers of Herbert Marcuse, Vol. 3, ed. by Douglas Kellner (London and New York: Routledge, Taylor and Francis Group, 2005).

"On The New Left," in The New Left and the 1960s: Collected Papers of Herbert Marcuse, Vol. 3, ed. by Douglas Kellner (London and New York: Routledge, Taylor and Francis Group, 2005).

"Philosophy at the Margins: Exploring the Philosophy of Work of the Elderly People in some Remote Areas of Negros Oriental," Social Ethics Society Journal of Applied Philosophy, 1:1 (October 2015).

"Shifting Pattern and Sophistication of the American Colonial Domination in the Philippines: From Colonialism to Technological Domination," Silliman Journal, 55:1 (January-June 2014).

"Technology, Technological Domination, and the Great Refusal: Marcuse's Critique of the Advanced Industrial Society," Kritike: An Online Journal of Philosophy, 4:1 (June 2010).

"The Freudian Marxist: Herbert Marcuse on the Psychology of Domination, Resistance, and Emancipation," Silliman Journal, 53:1 (January-June 2012).

"The History of Domination and Resistance in the Philippines: From the pre-Hispanic through the Spanish and American Period," 
Lumina: Interdisciplinary Research Journal of Holy Name University, 21:1 (March 2010).

Nadeau, Kathy, "Peasant Resistance and Religious Protests in Early Philippine Society: Turning Friars against the Grain," Journal for the Scientific Study of Religion, Vol. 41 No. 1 (March 2002).

Ochoa, Cecilia S., Siglo-Saka: A Century of Peasant Struggle and Contributions to Philippine Nationhood (Quezon City: Philippine Peasant Institute, 1998).

Putzel, James, A Captive Land: The Politics of Agrarian Reform in the Philippines (Quezon City: Ateneo de Manila University Press, 1992).

Salvador, Andres, "Racism and Immigration: Is it racist to limit immigration?" in Philo-notes (27 November 2017), $<$ https://philonotes.com/index.php/2017/11/27/racism-andimmigration/>. 